\title{
Hematology and serum biochemistry values of free-ranging Iberian wolves (Canis lupus) trapped by leg-hold snares
}

\author{
Nuno Santos • Helena Rio Maior • Mónia Nakamura • Sara Roque • Ricardo Brandão • \\ Francisco Petrucci-Fonseca • Vicente Palacios • Emílio Garcia • José Vicente López-Bao • \\ Luis Llaneza • Francisco Álvares
}

Received: 4 July 2014 /Revised: 28 October 2014 / Accepted: 30 November 2014

(C) Springer-Verlag Berlin Heidelberg 2014

\begin{abstract}
Hematology and serum biochemistry are important tools in assessing the health and physiological status of wildlife populations. Nevertheless, studies on free-ranging wolves (Canis lupus) are scarce, and no reference values are available neither for Iberian wolves nor for wolves captured with leghold snares. We report 37 hematology and serum biochemistry variables obtained from 26 free-ranging Iberian wolves captured with leg-hold snares between 2007 and 2014, including variables previously not reported in the literature. The values obtained are similar to the published reference intervals for Scandinavian wolves captured by darting from a helicopter, except for higher values for mean corpuscular hemoglobin concentration (MCHC), red blood cell distribution width (RDW), leukocyte count, creatinine kinase (CK), $\gamma$-globulins, and total bilirubin (TBIL) and lower values for alkaline phosphatase (ALP). We propose that differences in leukocyte count, CK, and TBIL are related to the method of capture, while differences in RDW, MCHC, ALP, and $\gamma$-globulins could reflect physiological adaptations to environmental
\end{abstract}

Communicated by C. Gortázar

N. Santos $(\bowtie)$

ICVS - Instituto de Investigação em Ciências da Vida e da Saúde, Universidade do Minho, Braga, Portugal

e-mail: pygargusvet@sapo.pt

N. Santos $\cdot$ H. R. Maior $\cdot$ M. Nakamura $\cdot$ L. Llaneza $\cdot$ F. Álvares CIBIO/InBio - Centro de Investigação em Biodiversidade e Recursos Genéticos, Universidade do Porto, Campus Agrário de Vairão, Vairão, Portugal

S. Roque $\cdot$ F. Petrucci-Fonseca

Grupo Lobo-Faculdade de Ciências da Universidade de Lisboa,

$\mathrm{C} 2,3^{\circ}$ piso, Lisbon, Portugal

S. Roque $\cdot$ F. Petrucci-Fonseca

CBA-Centro de Biologia Ambiental, Faculdade de Ciências da

Universidade de Lisboa, C2, $3^{\circ}$ piso, Lisbon, Portugal conditions, sampling, or pre-analytical artifacts. Lymphocyte count was lower and neutrophil/lymphocyte ratio was significantly higher in older, reproductive females, while ALP and phosphorus were higher in juvenile wolves. For the first time, we describe hematology and serum biochemistry values of free-ranging Iberian wolves captured with leg-hold snares. The data reported here is the first published reference for wolves captured with similar methods and for monitoring Iberian wolves populations' physiological and health status.

Keywords Iberian wolf $\cdot$ Hematology $\cdot$ Serum biochemistry $\cdot$ Reference intervals $\cdot$ Leg-hold snares

\section{Introduction}

Hematology and serum biochemistry values are important tools for health surveillance in free-ranging animal populations. This information is useful to assess the subclinical

\author{
R. Brandão \\ Associação ALDEIA - Centro de Ecologia, Recuperação e \\ Vigilância de Animais Selvagens (CERVAS), Gouveia, Portugal \\ V. Palacios $\cdot$ E. Garcia $\cdot$ L. Llaneza \\ A.RE.NA, Asesores en Recursos Naturales S.L., c/ Perpetuo \\ Socorro, $n^{\circ} 12$ - Entlo. 2B, Lugo, Spain \\ J. V. López-Bao \\ Research Unit of Biodiversity (UO/CSIC/PA), Oviedo University, \\ 33600 Mieres, Spain \\ J. V. López-Bao \\ Grimsö Wildlife Research Station, Swedish University of \\ Agricultural Sciences (SLU), SE-730 91, Riddarhyttan, Sweden
}


effects of pathogens (Brock et al. 2013) and physiological (López-Olvera et al. 2006), ecological (DelGiudice et al. 1991), or nutritional (Brock et al. 2013) status, among other issues. These parameters can be influenced by several intrinsic and extrinsic factors (Tryland 2006). Notably, the stress experienced by wild animals during capture should be taken into account as an extrinsic factor that interferes with hematology and serum biochemistry (Constable et al. 1998; Tryland 2006; Marks 2010) and which is influenced by the capture method (Marks 2010). Although leg-hold traps are arguably the most frequently used method to capture wolves (Van Ballenberghe 1984; Chavez and Gese 2006; Frame and Meier 2007), no data on hematological and serum biochemistry values of wolves captured with this method have been published.

Most published information on the hematology and serum biochemistry of wolves (Canis lupus) was obtained from captive individuals or from free-ranging pups (Seal et al. 1975; Seal and Mech 1983; Drag 1995; Kreeger 2003). Nevertheless, since captivity influences these parameters (Constable et al. 1998), and they may also change with factors such as age (Butler et al. 2006; Thorensen et al. 2009), it is important not only to determine hematology and serum biochemistry values in wild populations but also to investigate the sources of variation in these variables.

Moreover, to our knowledge, information on hematology and serum biochemistry have only been reported for wolf populations occurring in boreal environments (North American and Scandinavian populations; Constable et al. 1998; Butler et al. 2006; Thorensen et al. 2009), and no information is therefore available for wolves inhabiting other environments, such as the Iberian wolf populations located in a temperate Atlantic-Mediterranean habitat. The Iberian wolf range comprises mostly the northwestern Iberian Peninsula, covering an area of more than $140,000 \mathrm{~km}^{2}$. Total population is estimated at 2000-3000 individuals in 253-322 packs (Álvares et al. 2005), being the main population of this large carnivore in Western Europe (Boitani 2003).

The aim of this work was to (i) estimate the reference interval of 37 hematology and serum biochemistry variables from free-ranging Iberian wolves trapped with leg-hold snares and (ii) assess the influence of age on these variables.

\section{Methods}

Wolves were captured in four different areas of Northwestern Iberia, namely Alto Minho and Beira in Portugal and Galicia and Asturias in Spain (centroids of the study areas: $41^{\circ} 55^{\prime} 40^{\prime \prime}$ $\mathrm{N} 8^{\circ} 23^{\prime} 43^{\prime \prime} \mathrm{W}, 40^{\circ} 94^{\prime} 23^{\prime \prime} \mathrm{N} 7^{\circ} 68^{\prime} 50^{\prime \prime} \mathrm{W}, 42^{\circ} 24^{\prime} 43^{\prime \prime} \mathrm{N} 8^{\circ}$ $25^{\prime} 32^{\prime \prime} \mathrm{W}, 43^{\circ} 16^{\prime} 29^{\prime \prime} \mathrm{N} 4^{\circ} 58^{\prime} 55^{\prime \prime} \mathrm{W}$, respectively). This region is characterized by an Atlantic temperate wet climate without marked summer droughts and is part of the Eurosiberian vegetation zone, with marginal Mediterranean influence (Benayas and Scheiner 2002). The areas are characterized by different contexts of a human-dominated landscape with a mean human population density ranging from 6 to 108 inhabitants $/ \mathrm{km}^{2}$ (Naves et al. 2003; INE 2011; Llaneza et al. 2012; López-Bao et al. 2013). The landscape is predominantly heterogeneous, with areas at low altitudes and river valleys mainly covered by a mosaic of agricultural fields surrounding human settlements, while hillsides are occupied by scrublands, oak forest patches, and forest plantations.

Wolves were captured with Belisle ${ }^{\circledR}$ leg-hold snares (Edouard Belisle, Saint Veronique, PQ, Canada) and chemically immobilized, from July to March between 2007 and 2014. Snares were monitored twice every day, in the early morning and late afternoon. Wolves included in this study were captured for fitting telemetry devices in the context of research projects on the ecology of this species in Portugal and Spain. Trapping took place under permits 338/2007/CAPT, 258/2008/CAPT, 286/2008/CAPT, 260/2009/CAPT, 332/ 2010/MANU, 333/2010/CAPT, 336/2010/MANU, 26/2012/ MANU, and 72/2014/CAPT (Portugal) and E-0020/13-PNPE and 095/2013 - Xunta de Galicia (Spain).

A total of 26 wolves were captured during the study period. Sixteen animals were chemically immobilized by intramuscular injection of a mixture of ketamine (Imalgene ${ }^{\circledR}$, Merial, Lyon, France, $4.97 \pm 1.53 \mathrm{mg} / \mathrm{kg}$ ) and medetomidine (Domitor ${ }^{\circledR}$, Merial, Lyon, France, $0.10 \pm 0.03 \mathrm{mg} / \mathrm{kg}$ ) ( $n=$ 16). Ten juvenile or subadult wolves were sedated exclusively with medetomidine $(0.11 \pm 0.04 \mathrm{mg} / \mathrm{kg})$. Depending on each situation, injection was accomplished by handheld syringe, pole syringe, or blow-dart. Immobilization was reversed by the intramuscular injection of atipamezole (Revertor ${ }^{\circledR}$, Merial, Lyon, France, $0.40 \pm 0.01 \mathrm{mg} / \mathrm{kg}$ ). Age was estimated by dental pattern and wear, according to Gipson et al. (2000), assuming that births occurred in May each year (Kreeger 2003). Wolves were classified as juveniles ( $<1$ year), subadults $(1-$ 2 years), adults (2-7 years), and older ( $>7$ years). Breeding status was assessed in females using nipple measurements during capture (Mech et al. 1993) or by telemetry or genetic affiliation (unpublished data).

Blood samples were collected by venipuncture of the cephalic or saphenous veins $33 \pm 14$ min after administration of anesthesia and preserved in EDTA and clotting tubes, from which serum was separated by centrifugation at $1430 \mathrm{~g}$ for 10 min. Blood samples were kept refrigerated until analysis 9$102 \mathrm{~h}$ post-capture. Whole blood in EDTA and serum were analyzed for 31 analytical variables in a commercial laboratory (Inno, Braga, Portugal) using a Sysmex XT-2000iV (Sysmex Corporation, Kobe, Japan) hematology analyzer and a Mindray BS380 (Mindray Medical International Ltd, Shenzhen, China) clinical biochemistry analyzer. Briefly, cell counts were performed by flow cytometry, hemoglobin concentration by the SLS method, and proteins by electrophoresis. Enzyme, metabolite, and ion concentrations were 
determined by several methods available from the manufacturer (http://www.mindray.com/en/common/showSwf.jsp). Additionally, six more variables were calculated by standard formulas, based on the outcome of these analytically measured parameters (hematocrit, mean corpuscular hemoglobin $(\mathrm{MCH})$, mean corpuscular hemoglobin concentration (MCHC), red blood cell distribution width (RDW), neutrophil/lymphocyte, and albumin/globulins).

Following Lippi et al. (2006), the hematological values of samples presenting some degree of coagulation were excluded from further analysis ( $n=15$ values, from two wolves).

In compliance with the recommendations of the International Federation for Clinical Chemistry (IFCC) (Henny 2009), outliers were identified as values exceeding three interquartile ranges above the third quartile or below the first quartile and examined case by case, with emphasis on retaining them. Four observed values were identified as statistical outliers but were maintained in the dataset since there was no evidence that suggested these animals were not part of the normal population. For the purpose of determining intervals of variables previously shown to vary with age (Thorensen et al. 2009), values from juvenile wolves were excluded from the analysis ( $n=76$ values, from seven wolves), namely erythrocyte count, hematocrit, hemoglobin concentration, mean corpuscular volume (MCV), MCHC, alkaline phosphatase (ALP), total protein, albumin, albumin/globulin, $\gamma$-globulin, creatinine, calcium, chloride, magnesium, phosphate, and sodium values. Analytical values were Box-Cox transformed and sample interval was calculated by the robust method, after checking that the symmetry of the distribution was greater than 0.05 , according to the IFCC guidelines (Geffré et al. 2009). The robust method is recommended for the determination of reference values from datasets with small numbers of observations and involves iterative processes for identifying the location of the median and the spread of the distribution (Horn et al. 1998; Geffré et al. 2011). Reference Value Advisor 2.1 (Geffré et al. 2011) was used in determining the sample interval of each variable. Sample intervals are reported as median, standard deviation, robust sample interval, and minimum and maximum values.

The values obtained were compared with published data from Thorensen et al. (2009) and considered different whenever the median fell outside the reference range reported by those authors.

Each variable was compared by a non-parametric KruskalWallis test between age categories (juveniles $n=7$, subadults $n=7$, adults $n=9$, and older $n=3$ ). Values from juvenile wolves were included in the analysis to determine the influence of age on hematology and serum biochemistry variables. Statistical significance was set at $p<0.05$. SPSS 13.0 software (SPSS, Chicago, Illinois, USA) was used for statistical analyses. Nomenclature follows Geffré et al. (2009).

\section{Results}

The sample group consisted of 26 Iberian wolves, 17 from Alto Minho (12 adults, three subadults, two juveniles), five from Galicia (three subadults, two juveniles), two juveniles from Beira, and one juvenile from Asturias. The average weight was $36.9 \pm 3.8 \mathrm{~kg}$ for adult males, $31.0 \pm 3.8 \mathrm{~kg}$ for adult females, and $20.0 \pm 6.6 \mathrm{~kg}$ for juveniles. The mean estimated age of the 26 wolves was $34 \pm 29$ months while for the adult wolves, it was $59 \pm 26$ months. All trapped wolves were evaluated as clinically healthy at the moment of capture, although $25 / 26$ presented minor lesions associated with trapping (such as edema, skin abrasions, or superficial lacerations of the limb) and one presented severe lesions (radioulnar fracture-manuscript submitted).

Results on sample intervals are summarized in Tables 1 (hematology) and 2 (serum biochemistry). The median values for MCHC, RDW, leukocyte count, creatinine kinase (CK), total bilirubin (TBIL), and $\gamma$-globulins were higher than the reference range reported by Thorensen et al. (2009), while the median for ALP was lower. Older wolves ( $n=3$, all confirmed as reproductive females) tended to show lower lymphocyte counts ( $p=0.049$, Fig. 1a) and higher neutrophil/lymphocyte ratio $(p=0.024$, Fig. $1 b)$, while juveniles showed higher ALP $(p=0.013)$ and phosphorus $(p=0.013)$ (Fig. 1c, d, respectively) values, compared to other age categories.

\section{Discussion}

The reference interval for several hematology and serum biochemistry variables in free-ranging Iberian wolves captured with leg-hold snares is reported for the first time. Values in our sample were generally in accordance with those reported for free-ranging Scandinavian and North American wolves, except for MCHC, RDW, leukocyte count, CK, ALP, TBIL, and $\gamma$-globulin (Constable et al. 1998; Thorensen et al. 2009).

$\mathrm{MCHC}$ values in this study are similar to those reported for captive wolves (Kreeger 2003) and for dogs (Lawrence et al. 2013) but lower than those reported by Thorensen et al. (2009). Also wolves in our sample show lower MCV than those reported by Thorensen et al. (2009) (although the median lies within the reference interval), suggesting that the Scandinavian wolves analyzed by those authors presented slightly macrocytic hypochromic erythrocytes. This could be explained by a higher proportion of reticulocytes in Scandinavian wolves' red blood cells, but unfortunately neither the present study nor the study of Thorensen et al. (2009) performed reticulocyte counts. A slight anisocytosis was found in our sample which could be caused by storage macrocytosis in some blood samples (Katz et al. 2012).

We found higher leukocyte counts than those reported by Thorensen et al. (2009), which could be explained by the 
Table 1 Hematological sample intervals from trapped free-ranging Iberian wolves and previously reported reference intervals from Thorensen et al. (2009)

\begin{tabular}{llllllll}
\hline Variable & Number & Unit & Median & Standard deviation & Sample interval & Minimum-maximum & Previously reported values \\
\hline Hemoglobin $^{\mathrm{a}}$ & 16 & $\mathrm{~g} / \mathrm{dL}$ & 17.6 & 2.0 & $12.6-21.5$ & $14.1-20.2$ & $15.0-19.6$ \\
Erythrocyte count $^{\mathrm{a}}$ & 16 & $\times 10^{12} / \mathrm{L}$ & 7.24 & 0.89 & $5.30-9.30$ & $5.87-8.57$ & $6.36-8.19$ \\
Hematocrit $^{\mathrm{a}}$ & 16 & $\%$ & 51.9 & 7.1 & $35.7-67.5$ & $39.6-63.3$ & $51.0-63.0$ \\
$\mathrm{MCV}^{\mathrm{a}}$ & 16 & $\mathrm{fl}$ & 70.9 & 3.6 & $62.2-78.5$ & $63.4-76.6$ & $70.9-88.1$ \\
$\mathrm{MCH}^{\mathrm{a}}$ & 16 & $\mathrm{pg}$ & 23.95 & 0.62 & $22.6-25.4$ & $23.1-25.3$ & $27.4-33.2$ \\
$\mathrm{MCHC}^{\mathrm{a}}$ & 16 & $\mathrm{~g} / \mathrm{dL}$ & $34.3^{\mathrm{b}}$ & 1.9 & $30.8-39.1$ & $31.4-37.5$ & $11.5-14.1$ \\
$\mathrm{RDW}$ & 19 & $\%$ & $16.0^{\mathrm{b}}$ & 2.0 & $12.5-21.7$ & $13.7-19.7$ & $4.3-11.5$ \\
Leukocyte count & 21 & $\times 10^{9} / \mathrm{L}$ & $19.7^{\mathrm{b}}$ & 5.3 & $8.8-31.5$ & $10.6-31.1$ & \\
Neutrophil count & 21 & $\times 10^{9} / \mathrm{L}$ & 16.6 & 5.3 & $4.9-27.5$ & $8.4-28.5$ & $0-2.0$ \\
Eosinophil count & 21 & $\times 10^{9} / \mathrm{L}$ & 0.31 & 0.37 & $0.03-1.52$ & $0-0.33$ & \\
Basophil count & 21 & $\times 10^{9} / \mathrm{L}$ & 0.03 & 0.07 & $0.40-3.70$ & $0.45-3.73$ & \\
Lymphocyte count & 21 & $\times 10^{9} / \mathrm{L}$ & 1.70 & 0.78 & $0.10-1.80$ & $0.10-1.55$ & \\
Monocyte count & 21 & $\times 10^{9} / \mathrm{L}$ & 0.52 & 0.38 & $2.80-36.0$ & $3.26-30.77$ & \\
Neutrophil/lymphocyte & 21 & & 9.02 & 8.54 & $60.1-485.1$ & $53.0-520.0$ & $5.0-11.1$ \\
Platelet count & 20 & $\times 10^{9} / \mathrm{L}$ & 199.5 & 99.2 & $4.5-11.3$ & $54.0-567.0$ \\
MPV & 17 & $\mathrm{fL}$ & 9.9 & 1.4 & &
\end{tabular}

Samples presenting some degree of coagulation $(n=2)$ were excluded

${ }^{\text {a }}$ Juveniles were excluded from the analysis

${ }^{\mathrm{b}}$ Median outside the previously reported reference range

Table 2 Serum biochemistry sample intervals from trapped free-ranging Iberian wolves and previously reported reference intervals from Thorensen et al. (2009)

\begin{tabular}{|c|c|c|c|c|c|c|c|}
\hline Variable & Number & Unit & Median & Standard deviation & Sample interval & Minimum-maximum & Previously reported values \\
\hline Urea & 22 & $\mathrm{mg} / \mathrm{dL}$ & 53.7 & 20.3 & $30.6-115.3$ & $33.0-111.9$ & $21.6-90.8$ \\
\hline Creatinine $^{a}$ & 16 & $\mathrm{mg} / \mathrm{dL}$ & 0.88 & 0.24 & $0.40-1.40$ & $0.55-1.34$ & $0.60-1.49$ \\
\hline Aspartate aminotransferase & 14 & $\mathrm{UI} / \mathrm{L}$ & 200.7 & 310.1 & $52.7-2882.7$ & $72.2-1236.0$ & $38.0-312.0$ \\
\hline Alanine aminotransferase & 20 & $\mathrm{UI} / \mathrm{L}$ & 69.5 & 36.0 & $26.3-179.3$ & $20.2-177.4$ & $59.0-440.0$ \\
\hline Creatine kinase & 18 & $\mathrm{UI} / \mathrm{L}$ & $3213.8^{\mathrm{b}}$ & 8329.5 & $473.9-45,473.6$ & $497.3-35,173.0$ & $95.0-1315.0$ \\
\hline Alkaline phosphatase $^{\mathrm{a}}$ & 15 & $\mathrm{UI} / \mathrm{L}$ & $34.3^{\mathrm{b}}$ & 25.1 & $9.8-119.3$ & $12.5-101.6$ & $54.0-289.0$ \\
\hline Glucose & 20 & $\mathrm{mg} / \mathrm{dL}$ & 69.9 & 44.9 & $4.8-194.4$ & $4.1-191.0$ & $63.1-243.2$ \\
\hline Total bilirubin & 18 & $\mathrm{mg} / \mathrm{dL}$ & $0.20^{\mathrm{b}}$ & 0.25 & $0-1.10$ & $0.04-0.81$ & $0-0.12$ \\
\hline Sodium $^{\mathrm{a}}$ & 15 & $\mathrm{mEq} / \mathrm{L}$ & 146.4 & 6.8 & $131.4-163.4$ & $141.0-165.3$ & $145.0-154.0$ \\
\hline Potassium & 19 & $\mathrm{mEq} / \mathrm{L}$ & 5.26 & 0.55 & $3.60-6.10$ & $3.81-6.0$ & $4.3-5.7$ \\
\hline Chloride $^{\mathrm{a}}$ & 15 & $\mathrm{mEq} / \mathrm{L}$ & 112.7 & 12.6 & $82.6-144.1$ & $107.0-147.1$ & $109.0-124.0$ \\
\hline Total calcium ${ }^{\mathrm{a}}$ & 15 & $\mathrm{mg} / \mathrm{dL}$ & 7.70 & 1.60 & $4.70-12.0$ & $5.30-10.76$ & $7.6-10.4$ \\
\hline Phosphorus $^{\mathrm{a}}$ & 15 & $\mathrm{mg} / \mathrm{dL}$ & 4.20 & 1.67 & $1.60-8.80$ & $2.07-8.48$ & $1.86-5.88$ \\
\hline Total protein ${ }^{\mathrm{a}}$ & 15 & $\mathrm{~g} / \mathrm{dL}$ & 6.8 & 0.7 & $5.1-8.2$ & $5.6-7.6$ & $5.3-6.9$ \\
\hline Albumin $^{\mathrm{a}}$ & 15 & $\mathrm{~g} / \mathrm{dL}$ & 3.62 & 0.38 & $2.80-4.50$ & $2.79-4.57$ & $2.6-4.1$ \\
\hline Globulins & 22 & $\mathrm{~g} / \mathrm{dL}$ & 3.13 & 0.69 & $2.0-4.80$ & $2.10-5.12$ & \\
\hline $\begin{array}{l}\alpha 1-\text { Globulin } \\
\alpha 2-\text { Globulin }\end{array}$ & $\begin{array}{l}21 \\
21\end{array}$ & $\begin{array}{l}\mathrm{g} / \mathrm{dL} \\
\mathrm{g} / \mathrm{dL}\end{array}$ & $\begin{array}{l}0.31 \\
0.60\end{array}$ & $\begin{array}{l}0.17 \\
0.27\end{array}$ & $\begin{array}{r}0-0.80 \\
0.20-1.30\end{array}$ & $\begin{array}{l}0.04-0.70 \\
0.20-1.26\end{array}$ & $0.83-1.55$ \\
\hline$\beta-$ Globulin & 21 & $\mathrm{~g} / \mathrm{dL}$ & 1.08 & 0.42 & $0.50-2.40$ & $0.58-2.11$ & $0.76-1.52$ \\
\hline$\gamma-$ Globulin $^{\mathrm{a}}$ & 15 & $\mathrm{~g} / \mathrm{dL}$ & $0.80^{\mathrm{b}}$ & 0.50 & $0.30-2.40$ & $0.42-2.24$ & $0.23-0.63$ \\
\hline Albumin/globulin ${ }^{\mathrm{a}}$ & 15 & & 1.22 & 0.32 & $0.80-2.20$ & $0.93-1.96$ & \\
\hline
\end{tabular}

${ }^{a}$ Juveniles were excluded from the analysis

${ }^{\mathrm{b}}$ Median outside the previously reported reference range 
Fig. 1 Dot-plot graphics of the lymphocyte count (a), neutrophil/ lymphocyte (b), ALP (c), and phosphorus (d) by age categories. Bars represent the median of each dataset
A
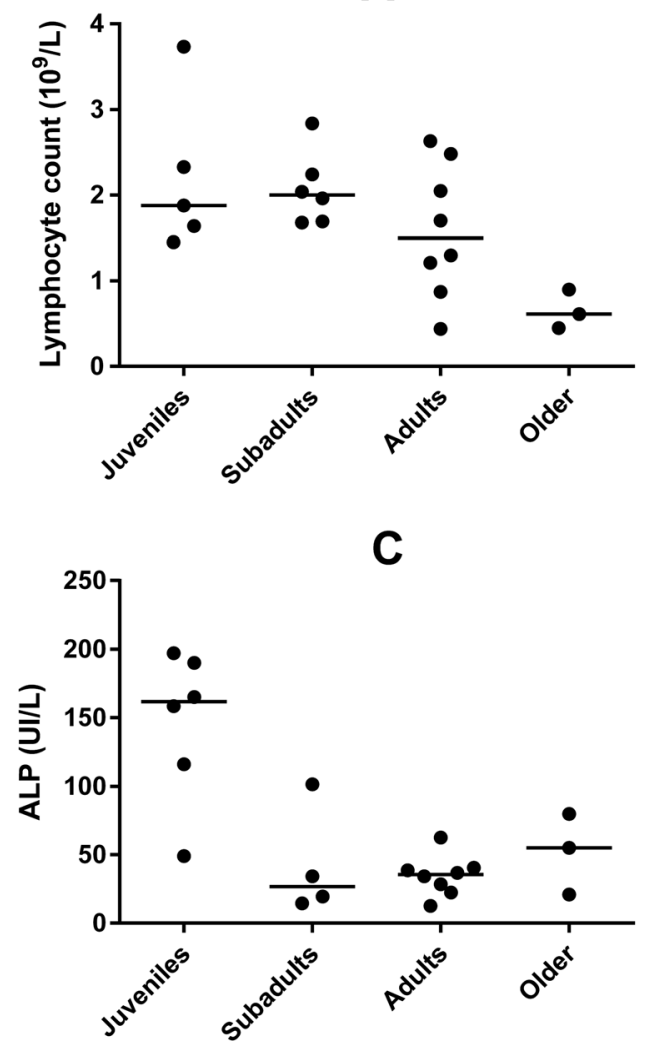

B
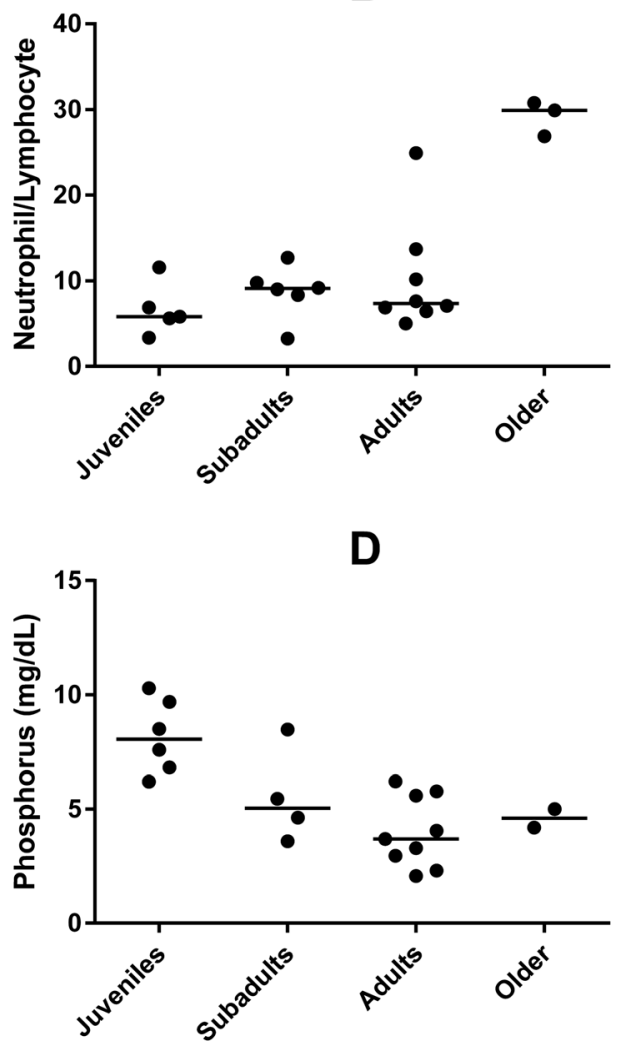

different capture methods used (trapping vs darting from a helicopter), with trapping inducing a more exuberant stress leukogram, as previously shown to occur in other carnivores (Cattet et al. 2003). The stress leukogram is a physiological response to a stressful event, characterized by leukocytosis with neutrophilia, monocytosis, and lymphopenia (Barger 2003). Unfortunately, Thorensen et al. (2009) did not report differential white blood cell counts, as it could allow further assessing this hypothesis. A stress leukogram pattern increases for up to $4 \mathrm{~h}$ after a stressful event (Bosson et al. 2012). The larger variability in leukocyte counts in this study compared to those reported by Thorensen et al. (2009) could be due to the also larger potential variability in delay between capture and handling. Furthermore, wolves in our sample tended to have higher CK and TBIL values than those reported by Thorensen et al. (2009). A possible explanation for all these differences is the longer duration of the capture event with the trapping method (56-720 $\mathrm{min}$ in the trap vs $<10-120$-min helicopter chase) promoting physical exertion-related rhabdomyolysis, hemolysis, and the establishment of a stress leukogram pattern. Biochemical markers of rhabdomyolysis and hemolysis have been shown to be elevated in other wild canids captured by leg-hold snares (Kreeger et al. 1990; Marks 2010). The effect of capture stress in freeranging wolves deserves further study in order to reduce the physiological alterations to the trapped animal caused by stress and physical exertion. Alkaline phosphatase values were lower and $\gamma$-globulin higher in Iberian wolves, which could be due to our sample possibly being composed of older animals. Three wolves in our sample presented results consistent with a mild monoclonal gammopathy in the $\gamma$ region. Monoclonal gammopathies have been associated with Ehrlichia spp. infection in dogs (Harrus et al. 1996), which is an infection previously detected in wolves in this region (Ferreira 2010). Upon capture, these three wolves showed no signs of disease and behaved normally for several months of GPS telemetry tracking.

Iberian free-ranging wolves showed high serum urea values compared with captive wolves (Constable et al. 1998), as also reported by Constable et al. (1998), Butler et al. (2006), and Thorensen et al. (2009) for Alaskan and Scandinavian freeranging wolves. Renal failure was excluded as a cause once all captured wolves also showed normal creatinine values. Growing evidence supports the hypothesis that this is a physiological phenomenon, possibly related to dietary and metabolic differences between free-ranging and captive animals (Thorensen et al. 2009). In fact, free-ranging animals could incorporate a higher proportion of low-quality protein in their diet and also show higher metabolic rate and protein catabolism, leading to higher urea values compared to captive wolves.

Life expectancy for free-ranging wolves is estimated to be up to 9 years (Lovari et al. 2006); we were able to capture three wolves estimated to be more than 7 years old, from three different packs in the Alto Minho study area. Interestingly, all 
were confirmed as reproductive females in the previous season $(n=2)$ or in the next season $(n=1)$, relative to the capture. These adult reproductive females showed a marked tendency for lower lymphocyte counts and higher neutrophil/ lymphocyte ratio, which could be caused by their age, gender, or reproductive status. Lymphocyte counts decreasing and neutrophil counts increasing with age have been described in dogs as part of the immunosenescence but not in such a dramatic way (Lawrence et al. 2013). In North American red squirrels (Tamiasciurus hudsonicus), females showed higher stress markers after trapping compared to males (Bosson et al. 2012). Breeding wolves have been shown to have higher stress markers (e.g., corticosteroids) compared to nonbreeding wolves (Creel 2005). Together, these results suggest that older reproductive females show a more exuberant stress response, as indicated by the leukograms obtained in our study, although the small number of such wolves that were analyzed does not allow for stronger conclusions. Phosphorus and ALP values were higher in juveniles compared to other age categories, as previously reported for Scandinavian wolves (Thorensen et al. 2009) and for dogs (Lawrence et al. 2013). Nevertheless it should be mentioned that most juvenile wolves in this study were sedated with medetomidine only, while all adults were anesthetized with ketamine-medetomidine, and ketamine was shown to decrease serum phosphorus values (Rovirosa-Hernández et al. 2011).

Although based on a relatively small sample size, this study reports for the first time hematology and serum biochemistry values for free-ranging wolves captured by leg-hold snares. This study supports previous evidence in other carnivore species that the stress imposed by the capture method greatly influences some of the variables analyzed (e.g., Kreeger et al. 1990; Marks 2010). As such, the values reported here should be used to monitor the health and physiological status of wolves captured using similar methods. Overall, the population under study showed a good health condition, so the values reported can also be used as reference to prospectively monitor the health and physiological status of the Iberian wolf population.

\begin{abstract}
Acknowledgments We thank Nuria Fandos and Carla Ferreira, rangers from Xunta de Galicia and Parque Nacional de los Picos de Europa, and volunteers who helped during the trapping sessions. The wolves were captured under projects financed by Associação de Conservação do Habitat do Lobo Ibérico (ACHLI) in Portugal and by Picos de Europa National Park, Ministerio de Agricultura, Alimentación y Medio Ambiente, and Xunta de Galicia in Spain. Sara Roque benefited from grant SFRH/BD/12291/2003 from Fundação para a Ciência e a Tecnologia. José V. López-Bao was supported by a postdoctoral contract from the Spanish Ministry of Economy and Competitiveness. This is the paper no. 5 from the Iberian Wolf Research Team.
\end{abstract}

Ethical declaration All work was conducted in full compliance of the national laws and ethical standards.

\section{References}

Álvares F, Barroso I, Blanco J, Correia J, Cortés Y, Costa G, Llaneza L, Moreira L, Nascimento J, Palacios V, Petrucci-Fonseca F, Pimenta V, Roque S, Santos E (2005) Wolf status and conservation in the Iberian Peninsula. International Congress Frontiers of Wolf Recovery, Colorado Springs

Barger AM (2003) The complete blood cell count: a powerful diagnostic tool. Vet Clin N Am Small Anim Pract 33(6):1207-1222

Benayas J, Scheiner S (2002) Plant diversity, biogeography and environment in Iberia: patterns and possible causal factors. J Veg Sci 13:245-258

Boitani L (2003) Wolf conservation and recovery. In: Mech LD, Boitani L (eds) Wolves. Behavior, ecology and conservation. University of Chicago Press, Chicago, pp 317-340

Bosson C, Islam Z, Boonstra R (2012) The impact of live trapping and trap model on the stress profiles of North American red squirrels. J Zool 288:159-169

Brock P, Hall A, Goodman S, Cruz M, Acevedo-Whitehouse K (2013) Applying the tools of ecological immunology to conservation: a test case in the Galapagos sea lion. Anim Conserv 16:19-31

Butler M, Warren J, Ballard B, Whitlaw H (2006) Physical characteristics, hematology, and serum chemistry of free-ranging gray wolves, Canis lupus, Southcentral Alaska. Can Field Nat 120(2):205-212

Cattet MR, Christison K, Caulkett NA, Stenhouse GB (2003) Physiologic responses of grizzly bears to different methods of capture. J Wildl Dis 39(3):649-654

Chavez A, Gese E (2006) Landscape use and movements of wolves in relation to livestock in a wildland-agriculture matrix. USDA National Wildlife Research Center - Staff Publications, Paper 413

Constable P, Hinchcliff K, Demma N, Callahan M, Dale B, Fox K, Adams L, Wack R, Kramer L (1998) Serum biochemistry of captive and free-ranging wolves (Canis lupus). J Zoo Wildl Med 29:435-440

Creel S (2005) Dominance, aggression, and glucocorticoid levels in social carnivores. J Mammal 86(2):255-264

DelGiudice G, Mech D, Seal U (1991) Gray wolf density and its association with weights and hematology of pups from 1970 to 1988. J Wildl Dis 27(4):630-636

Drag M (1995) Serum chemistry values for captive Mexican wolves. In: Carbyn LN, Fritts SH, Seip DR (eds) Ecology and conservation of wolves in a changing world. Canadian Circumpolar Institute, University of Alberta, Edmonton, pp 447-451

Ferreira ICBB (2010) Rastreio sorológico de alguns agentes de zoonoses em canídeos silvestres no Norte de Portugal. MSc dissertation, Faculty of Veterinary Medicine, University of Lisbon (In Portuguese)

Frame P, Meier T (2007) Field-assessed injury to wolves captured in rubber-padded traps. J Wildl Manag 71(6):2074-2076

Geffré A, Friedrichs K, Harr K, Concordet D, Trumel C, Braun J (2009) Reference values: a review. Vet Clin Pathol 38(3):288-298

Geffré A, Concordet D, Braun J, Trumel C (2011) Reference value advisor: a new freeware set of macroinstructions to calculate reference intervals with Microsoft Excel. Vet Clin Pathol 40(1):107-112

Gipson P, Ballard W, Nowak R, Mech D (2000) Accuracy and precision of estimating age of gray wolves by tooth wear. J Wildl Manag 64(3):752-758

Harrus S, Waner T, Avidar Y, Bogin E, Peh HC, Bark H (1996) Serum protein alterations in canine ehrlichiosis. Vet Parasitol 66(3):241-249

Henny J (2009) The IFCC recommendations for determining reference intervals: strengths and limitations. J Lab Med 33(2):45-51

Horn PS, Pesce AJ, Copeland B (1998) A robust approach to reference interval estimation and evaluation. Clin Chem 44(3):622-631

INE (2011) Censos 2011. Instituto Nacional de Estatística. http://censos. ine.pt/xportal/xmain? $\mathrm{xpid}=$ CENSOS\&xpgid $=$ censos 2011 apresentacao. Accessed 12 June 2014

Katz VL, Lentz G, Lobo RA, Gershenson D (2012) Small animal clinical diagnosis by laboratory methods (fifth edition). Elsevier, Saint Louis 
Kreeger T (2003) The internal wolf: physiology, pathology and pharmacology. In: Mech D, Boitani L (eds) Wolves: behavior, ecology and conservation. The University of Chicago Press, Chicago, pp 192-217

Kreeger TJ, White P, Seal US, Tester JR (1990) Pathological responses of red foxes (Vulpes vulpes) to foothold traps. J Wildl Manag 54(1): $147-160$

Lawrence J, Chang Y-MR, Szladovits B, Davison LJ, Garden OA (2013) Breed-specific hematological phenotypes in the dog: a natural resource for the genetic dissection of hematological parameters in a mammalian species. PLoS ONE 8(11):e81288. doi:10.1371/journal.pone.0081288

Lippi G, Salvagno G, Montagnana M, Brocco G, Guidi G (2006) Influence of hemolysis on routine clinical chemistry testing. Clin Chem Lab Med 44(3):311-316

Llaneza L, López-Bao JV, Sazatornil V (2012) Insights into wolf presence in human-dominated landscapes: the relative role of food availability, humans and landscape attributes. Divers Distrib 18:459-469

López-Bao JV, Sazatornil V, Llaneza L, Rodríguez A (2013) Indirect effects on heathland conservation and wolf persistence of contradictory policies that threaten traditional free-ranging horse husbandry. Conserv Lett 6:448-455

López-Olvera J, Marco I, Montané J, Lavín S (2006) Haematological and serum biochemical values of Southern chamois (Rupicapra pyrenaica). Vet Rec 158:479-484

Lovari S, Sforzi A, Scala C, Fico R (2006) Mortality parameters of the wolf in Italy: does the wolf keep himself from the door? J Zool 272(2):117-124
Marks C (2010) Haematological and biochemical responses of red foxes (Vulpes vulpes) to different capture methods and shooting. Anim Welf 19:223-234

Mech LD, Meier TJ, Seal US (1993) Wolf nipple measurements as indices of age and breeding status. Am Midl Nat 266-271

Naves J, Wiegand T, Revilla E, Delibes M (2003) Endangered species constrained by natural and human factors: the case of brown bears in northern Spain. Conserv Biol 17(5):1276-1289

Rovirosa-Hernández MJ, García-Orduña F, Caba M, Canales-Espinosa D, Hermida-Lagunes J, Torres-Pelayo VR (2011) Blood parameters are little affected by time of sampling after the application of ketamine in black howler monkeys (Alouatta pigra). J Med Primatol 40:294-299

Seal US, Mech LD (1983) Blood indicators of seasonal metabolic patterns in captive adult gray wolves. J Wildl Manag 704 715

Seal US, Mech LD, Van Ballenberghe V (1975) Blood analyses of wolf pups and their ecological and metabolic interpretation. J Mammal 64-75

Thorensen S, Arnemo J, Liberg O (2009) Hematology and serum clinical chemistry reference intervals for free-ranging Scandinavian gray wolves (Canis lupus). Vet Clin Pathol 38(2):224-229

Tryland M (2006) "Normal" serum chemistry values in wild animals. Vet Rec 158:211-212

Van Ballenberghe V (1984) Injuries to wolves sustained during livecapture. J Wildl Manag 48(4):1425-1429 